\title{
Publicystyka wybranych czasopism konserwatywnych wobec zbliżenia Polski i ZSRR w latach 1932-1933
}

ADRIAN MATUŁA - ukończył studia doktoranckie na Wydziale Historii i Dziedzictwa Kulturowego Uniwersytetu Papieskiego Jana Pawła II. Przygotowuje rozprawę na temat wizerunku Związku Sowieckiego na łamach czasopism konserwatywnych w latach I929-1939. 
Spory o Rzeczpospolita. Przeglad wybranych dyskusji politycznych $i$ ustrojowych w ostatnim stuleciu, red. P. Gofron, A. Matuła, A. Paderewska, Kraków 2020, s. 134-154.

DOI: http://dx.doi.org/10.15633/9788374388061.09

$\Lambda_{\text {międzywojennego, musimy mieć na uwadze to, iż nie stanowiły }}^{\text {nalizujacteksty polskich czasopismach konserwatywnych z okresu }}$ on jednego ideowo spójnego ruchu ${ }^{1}$. Zbudowany on był, raczej z mocno autonomicznych grup, systematyzowanych najczęściej w oparciu o region-miasto, w którym czasopismo wychodziło ${ }^{2}$. Na tej podstawie możemy wyszczególnić najważniejsze dzienniki konserwatywne i grupy z nimi związane, które będą też analizowane w poniższym artykule: konserwatystów krakowskich związanych z najdłużej działającym pismem konserwatywnym „Czasem”3 grupę wileńską, tzw. „Żubrów” ze „Słowem”, wielkopolskich konserwatystów związanych z „Dziennikiem Poznańskim”. Wreszcie działających w Warszawie, choć na tym terenie istniały dwa znaczące czasopisma: „Nasza Przyszłość” związana z Janem Bobrzyńskim i „Dzień Polski” ${ }^{4}$. Dodatkowo autor przeanalizował

I Nie należy jednak, jak słusznie zauważył Jacek Bartyzel, mówić o niemożności zdefiniowania pojęcia konserwatyzmu. Wspomniany powyżej autor przedstawia, wydaje się pełne wyjaśnienie pojęcia, zob. J. Bartyzel, Konserwatyzm bez kompromisu. Studium z dziejów zachowawczej myśli politycznej w Polsce wXX wieku, Toruń 2002, s. 22-38.

2 G. Zackiewicz, Polska myśl polityczna wobec systemu radzieckiego I9I8-I939, Kraków 2004, s. 4I3.

3 „Czas” działał w Krakowie do I 934 roku, następnie został przeniesiony do Warszawy i połączony z „Dniem Polskim”, zob. S. Rudnicki, W. Władyka, Prasa konserwatywna Drugiej Rzeczpospolitej. Zarys problematyki i przeglad tytutów, „Rocznik Historii Czasopiśmiennictwa Polskiego” I 4 (I975) nr 4, s. 449.

4 Autor zdecydował się, ze względu na wykazanie różnic pomiędzy poszczególnymi organami prasowymi, na analizę poglądów przedstawianych na łamach „Naszej Przyszłości”. Redaktorzy, a szczególnie Jan Bobrzyński, wykazywali 
publicystykę neokonserwatystów związanych z „Buntem Młodych”. W skład tego środowiska wchodziło najmłodsze pokolenie publicystów, które czerpało z tradycji konserwatywnej i miało powiązania w każdym z wyżej wymienionych ośrodków ${ }^{5}$. Ważne w kontekście poniższej analizy, po odejściu przeciwników sanacji do obozu narodowego, zachowawcy poparli rządy pomajowe, przy zachowaniu dużej samodzielności głoszenia swoich poglądów. Przekonania mieli często bardzo krytyczne, za co zostawali karani konfiskatą lub cenzurą numerów, jak miało to miejsce w przypadku „Czasu” po artykułach na temat procesu brzeskiego. Przeważnie uznawali oni główne linie polityki rządów sanacyjnych, jednak pomiędzy redakcjami poszczególnych czasopism, często dochodziło do znaczących różnic w ocenie jej realizowania.

Wśród konserwatystów, pomimo iż należeli oni do różnych grup, panowała pełna zgoda co do niemożności przyjęcia założeń komunizmu w sferze doktrynalnej, czy też ekonomicznej. W okresie wprowadzania pierwszego planu pięcioletniego wieszczono jego niewykonalność. Co więcej zachowawcy łączyli porażki na polu ekonomicznym i słabość gospodarki z osłabianiem się władzy bolszewików. Można nawet stwierdzić, iż nie rozważali oni w początkowych okresach możliwości upadku, lecz byli absolutnie pewni obalenia komunizmu ${ }^{6}$. Błędne przekonanie o rychłym krachu systemu komunistycznego, częściowe powodzenie planu pięcioletniego, stabilizacja władzy Stalina, wprowadzały nowy nurt w rozważania, które zaczęły dotyczyć konieczności wypracowania przez Polskę długoterminowej polityki wschodniej.

się dużą oryginalnością myśli. „Dzień Polski” natomiast w omawianym okresie w swoich poglądach zbliżony był do „Czasu”. O związkach pomiędzy redakcjami, zob. S. Rudnicki, W. Władyka, Prasa konserwatywna Drugiej Rzeczpospolitej. Zarys problematyki i przegląd tytutów, „Rocznik Historii Czasopiśmiennictwa Polskiego" I 4 (I975) nr 4, s. 440-448.

5 W. Władyka, Publicystyka polityczna neokonserwatystów w latach I926-I935, „Rocznik Historii Czasopiśmiennictwa Polskiego” I 5 (I976) nr 4, s. 459-460.

6 G. Zackiewicz, Polska myśl polityczna wobec systemu radzieckiego I9I8-I939, dz. cyt., s. 4I9. 


\section{Wobec podpisania polsko-sowieckiego paktu o nieagresji}

Pierwszym tego typu działaniem było podpisanie wielostronnej umowy międzynarodowej pomiędzy Polską, ZSRR i innymi krajami 1929 roku, określanej protokołem Moskiewskim, bądź protokołem Litwinowa ${ }^{7}$. Jego konsekwencją, był akt najbardziej nas interesujący, mianowicie zawarty 25 lipca 1932 roku w Moskwie pakt o nieagresji, podpisany ze strony polskiej przez Stanisława Patka, a ze strony rosyjskiej przez Nikołaja Krestinskiego ${ }^{8}$. Uzupełniony on został o pochodzącą z 3 lipca I933 roku konwencją o określeniu napaści, która została podpisana w Londynie9. Rozbieżności wśród publicystów związanych z konserwatywnymi czasopismami zaistniały przede wszystkim na polu różnego pojmowania sytuacji geopolitycznej, w jakiej znajdowała się Polska, a co za tym idzie - wpływu owego paktu na jej położenie. Wiązało się to, jak zostało wcześniej wspomniane, z geograficznym położeniem i wynikającą z tego różną interpretacją zagrożenia międzynarodowego. Dlatego można zauważyć mniejsze zainteresowanie polityką wschodnią w ośrodku poznańskim, który obawiał się akcji ze strony niemieckiej i na nich skupiał swoją uwagę, a większe - w ośrodku wileńskim z racji bliskości zagrożenia komunistycznego.

Podpisanie paktu o nieagresji stanowiło ważną cenzurę w przedstawieniach Związku Radzieckiego, jakich dokonywano na łamach zachowawczych czasopism. Przed tym faktem dominowały jednoznacznie negatywne opinie na temat wschodniego sąsiada. Władza bolszewicka, a szczególnie działania i wpływy Kominternu na terenie Polski budziły ogromne obawy wśród publicystów. Uważano, iż ko-

7 W. Materski, Na widecie. II Rzeczpospolita wobec sowietów I9I8-I943, Warszawa 2005 , s. 338.

8 W. Materski, Na widecie. II Rzeczpospolita wobec sowietów I9I8-I943, dz. cyt., s. $39 \mathrm{I}$.

9 W. Materski, Na widecie. II Rzeczpospolita wobec sowietów I9I8-I943, dz. cyt., S. 4I 4 . 
munistyczna koncepcja ładu społecznego jest niemożliwa do pogodzenia z cywilizacją europejską ${ }^{\mathrm{I}}$. Co więcej, poprzez próby podjęcia współpracy z Krajem Rad, jak stwierdzał Edward Paszkowski związany z krakowskim „Czasem”, Europa sama finansowała swoją klęskę. Kupując od bolszewików towary po zaniżonych cenach oraz udzielając im kredytów, Zachód kierował się tylko krótkoterminowym zyskiem, nie zauważając niebezpieczeństw wynikających z takiego zachowania. Kapitał uzyskany w ten sposób służyć miał bowiem sowietom do finansowania działalności Kominternu na Zachodzie, natomiast jego celem było obalenie świata kapitalistycznego. Dlatego podsumowując doszło w jego opinii do sytuacji, w której to świat zachodni swoimi funduszami wspierał największego wroga, otwarcie głoszącego walkę z nim ${ }^{\text {II }}$.

W środowisku związanym z „Dziennikiem Poznańskim” znajdujemy charakterystyczną interpretację Związku Radzieckiego. Bolszewizm w opinii anonimowego publicysty był międzynarodowym spiskiem mającym na celu rozpalenie światowej rewolucji. Miał być to pierwszy taki przypadek w historii, gdy organizacja działała w każdym zakątku ziemi, wykorzystując wszelkie zasoby kraju gościnnego ${ }^{\text {I2 }}$. Z tego powodu, we wszystkich redakcjach, obawiano się wpływów sowieckich na ziemiach polskich, które dostrzegano wśród nurtów socjalistycznych, liberalnej inteligencji, wolnomyślicieli, czy też młodzieży akademickiej. W odpowiedzi na zagrożenie komunistyczne formułowano nawet najbardziej skrajne żądania, jak te, które sformułował Aleksander Laczysław:

Io Od początków refleksja konserwatywna odrzucała komunizm jako zagrożenie dla zachodniej cywilizacji oraz przedstawianej przez konserwatystów wizji człowieka, zob. B. Szlachta, Krytyka komunizmu w polskiej myśli katolickiej $i$ konserwatywnej, w: Antykomunizm po komunizmie, red. J. Kloczkowski, Kraków 2002, s. I 5-49.

I I E. Paszkowski, Narastające niebezpieczeństwo, „Czas” 84 (I93 I) nr Io2, s. I.

I 2 Sieć terrorystów moskiewskich oplata caty świat, „Dziennik Poznański” 74 (I932) nr I78, s. I. 
Dlatego wszelkie przejawy bolszewizmu w Polsce, powinniśmy zwalczać bezwzględnie, nie licząc się z żadnymi opiniami różnych wyroczni zagranicznych ${ }^{13}$.

Po podpisaniu paktu o nieagresji publicystyka konserwatywna zaczęła ewoluować, często w stronę coraz bardziej przychylnych komentarzy, przy czym zaczęły uwypuklać się różnice pomiędzy redakcjami. Nieprzejednane stanowisko po podpisaniu dokumentu tradycyjnie zajmował Marian Zdziechowski, który komunizm uznawał zawsze za największe niebezpieczeństwo, nie tylko dla Polski, ale również dla całej cywilizacji europejskiej. Już w I93I roku krytykował władze za jakiekolwiek próby zbliżenia się z rządem sowieckim. Brak zorganizowanego oporu przeciwko bolszewikom przedstawiał on w swoich wypowiedziach jako zaślepienie wywołane wizją korzyści finansowych. Na łamach „Naszej Przyszłości” pisał:

Geszeft zaćmił wam świat idei, nie jesteście zdolni do idei, oni zaś ideę mają ideę szatańską [...] wy z nimi to, znaczy z diabłem siadacie do stołu i z nimi [...] zawieracie przymierze.

Jednakże autor ten pozostawał osamotniony w swoich apelach, gdyż większość publicystów konserwatywnych, mniej lub bardziej pozostała lojalna wobec polityki wschodniej sanacji ${ }^{14}$.

Czasopismo kierowane przez Jana Bobrzyńskiego bardzo ostrożnie podchodziło do kwestii polityki zagranicznej, kierowanej przez piłsudczyków, i możliwości jej krytyki. Związane to było z ścisłą współpracą warszawskich zachowawców z obozem władzy, a także otrzymywaniem subwencji z budżetów różnych ministerstw ${ }^{15}$. Nie uciekano jednak od formułowania swoich analiz dotyczących polityki wschodniej państwa polskiego. Przed podpisaniem paktu o nieagresji często powtarzano

I 3 A. Laczysław, Bałtyk-Morze Czarne, „Nasza Przyszłość” 3 (I930), s. 6o.

I 4 M. Zdziechowski, Duchowa podstawa walki z bolszewizmem, „Nasza Przyszłość" I 2 (I93 I), s. 47-48.

I 5 W. Mich, Publicystyka polityczna „Naszej Przysztości” I930-I939, dz. cyt., s. 35. 
o konieczności izolacji Związku Radzieckiego na arenie międzynarodowej. Traktowano go jako zagrożenie dla całej cywilizacji zachodniej. Co więcej w publicystyce „Naszej Przyszłości” stale powtarzano tezy dotyczące agresywnego nastawienia władz sowieckich i możliwości ataku na państwa zachodnie ${ }^{16}$. Adam Romer - podobnie jak Edward Paszkowski - uważał, iż państwa europejskie, handlując z ZSRR, same działają na swoją zgubę. Proponował on program zjednoczenia Europy, gdyż tylko zbudowanie jednolitego frontu antybolszewickiego miało pozwolić na zwycięstwo ze Związkiem Radzieckim ${ }^{17}$.

\section{Polska wobec ZSRR. Zarys koncepcji politycznych na lamach czasopism}

Na łamach czasopisma starano się wypracować własne podejście w prowadzeniu polskiej dyplomacji. W swoim tekście Karol Koźmiński krytykował Polskę za brak koncepcji polityki wschodniej w Polsce i podejmowanie tylko działań doraźnych. Proponował on żądania: wyłącznie gotówki za towary eksportowe, import tylko dóbr koniecznych, produkowania mniej, lecz wyższej jakości produktów oraz pozbycia się złudzenia, iż rynki wschodnie Polski, będą odpowiadać tym z czasów Królestwa Polskiego ${ }^{18}$. Po podpisaniu paktu o nieagresji doszło do przewartościowania w koncepcjach dotyczących polityki wobec wschodniego sąsiada. Dostosowując się do oficjalnej linii polskiej dyplomacji redakcja „Naszej Przyszłości” przestała uważać bolszewizm za największe zagrożenie, formułując tezę o zagrożeniu ze strony rosyjskości. Jak dowodził Jan Bobrzyński, podczas obiadu przyjaciół „Naszej

I6 W. Mich, Publicystyka polityczna „Naszej Przysztości” I930-1939, dz. cyt., s. I27-I 28 .

I7 A. Romer, Iluzja solidaryzmu Europy, „Nasza Przyszłość” Io (I93 I), s. I 8-23.

I 8 K. Koźmiński, Na marginesie dumpingu sowieckiego, „Nasza Przyszłość” I 2 (I93I), s. I7-I9. 
Przyszłości”, bolszewizm był doktryną , jawnie wywrotową, jaskrawie amoralną i realizowaną z rozgłośnym okrucieństwem”, dlatego tež opowiedzieć za nią mogły się tylko „ostatnie szumowiny społeczne”. Polacy wychowani na wzorcach zachodnich mieli nigdy nie ulec wpływom doktryny komunistycznej ${ }^{19}$. Inaczej przedstawiały się niebolszewickie wpływy rosyjskie. Rosję traktowano jako całkowicie oddzielną kulturowo, a przez to destrukcyjnie wpływające na polską świadomość, jak miało to miejsce podczas zaborów ${ }^{20}$. Formułując nową koncepcje polityki wschodniej opierano się na zasadach realizmu politycznego. Korzyści, jakie dawał pakt na polu ekonomiczno-gospodarczym, miały być wykorzystywane tylko w wypadku, gdy Polska osiągnie wymierne zyski z takiej współpracy. Zaznaczano, iż nie można uzależniać produkcji krajowej od rynku wschodniego, jak również dostosowywać polityki zagranicznej do przemian zachodzących w ZSRR ${ }^{21}$. Współpracę pomiędzy dwoma państwami traktowano jako przejściową, gdyż w opinii redakcji zarówno Rosja biała, jak i czerwona stanowiła zawsze siłę agresywną 22.

Podpisanie konwencji o określeniu napaści przyjęto z dużą dozą optymizmu, zaczęto traktować ZSRR jako stały element w koncepcjach polskiej polityki zagranicznej. Polska poprzez podpisanie paktu miała udowodnić swoją samodzielność, a także wzmocniła swoją pozycję międzynarodową, co więcej napełniła treścią puste jak dotąd hasło mocarstwowości ${ }^{23}$. W kolejnych artykułach twierdzono nawet,

I9 Problem rosyjski. Komunikat z obiadu dyskusyjnego Kota Przyjaciót „Naszej Przysztości”, „Nasza Przyszłość” 3 I (1933), s. 9.

20 Problem rosyjski. Komunikat z obiadu dyskusyjnego Kota Przyjaciót „Naszej Przysztości”, dz. cyt., s. 4I-42.

2 I Problem rosyjski. Komunikat z obiadu dyskusyjnego Kota Przyjaciót „Naszej Przysztości”, dz. cyt., s. I3-I6.

22 Problem rosyjski. Komunikat z obiadu dyskusyjnego Kota Przyjaciót „Naszej Przysztości”, dz. cyt., s. I6-I9.

23 J. K., Pod znakiem politycznej „Unii Wschodniej”, „Nasza Przyszłość” 34 (I933), s. 5 I-56. 
że Polska nie tylko zlikwidowała niebezpieczeństwo wschodnie, lecz zabezpieczyła się przed zachodnim. Poprzez pakt, Polska polityka zagraniczna mogła zostać przeorientowana i oprzeć się na wschodnich sojusznikach ${ }^{24}$. Ogromną zmianę, jaką wywołały omawiane dokumenty dyplomatyczne w początkowo antyrosyjskim piśmie, redakcja tłumaczyła pragmatyzmem. Traktaty z bolszewikami traktowano jako konieczność zabezpieczenia się ze Wschodu, gdyż nie widziano możliwości porozumienia się z Niemcami ${ }^{25}$.

Ośrodek, który przykładał większą wagę do polityki zachodniej niż wschodniej, czyli związany z konserwatystami wielkopolskimi „Dziennik Poznański” stosunkowo mało miejsca poświęcał rozważaniom dotyczącym stosunkom polsko-sowieckim. Decyzję o podpisaniu paktu przyjęto w sposób umiarkowany. Odwoływano się do wcześniejszych artykułów dotyczących zagrożeń pochodzących ze strony Kominternu. Strajki, które ówcześnie się odbywały w Ottawie, czy Brukseli, potwierdzały tezę, iż Związek Sowiecki nie pozbył się planów wywołania rewolucji i realizuje je za pomocą III Międzynarodówki. Szczególne obawy budziły działania tej organizacji oraz połączonego z nią świetnie zorganizowanego szpiegostwa sowieckiego ${ }^{26}$. Opisywano ją raczej jako międzynarodowy spisek komunistyczny mający na celu przejąć władzę poprzez zamach stanu. Jako przykład wskazywano Niemcy, które dłuższy czas miały pozytywne stosunki dyplomatyczne, lecz nie przeszkadzało to Kominternowi prowadzenia rewolucyjnej agitacji ${ }^{27}$. Zalecano więc dużą ostrożność w kontaktach z komunistami, uważając, iż istnieją nieprzekraczalne granice w sferze bezpieczeństwa wewnętrznego, których nie można zasłonić korzyściami ekonomicznymi.

24 W. Mich, Publicystyka polityczna „Naszej przysztości” I930-I939, dz. cyt., s. I88-I9I.

25 I. K., Wojna! Wojna!, „Nasza Przyszłość” 32 (I933), s. 23-24.

26 L. I., Tajemnice szpiegostwa sowieckiego, „Dziennik Poznański” 74 (I932) nr I 64, s. 7 .

27 K., Sieć terrorystów moskiewskich oplata caty świat, „Dziennik Poznański” 74 (I932) nr I78, s. I. 
Poglądy te dosyć szybko przysłoniła publicystyka wskazująca na pozytywy płynące z podpisania paktu. Wynikało to, jak już zostało zasygnalizowane, z wizji sytuacji geopolitycznej Polski, gdzie zagrożeniem była agresywna polityka ze strony Niemiec. Już w trakcie negocjacji pojawiały się artykuły dopuszczające ścisłą współpracę pomiędzy rządem polskim i sowieckim w celu zwalczenia zachodniego sąsiada ${ }^{28}$. Po podpisaniu paktu możemy natomiast spotkać się z komentarzami jak najbardziej pozytywnymi, a wręcz fakt ten ogłaszano jako spory sukces. Rozwinięciem działań Polski na Wschodzie miały być poszerzone kontakty gospodarcze, choć zastrzegano, a raczej przestrzegano, by nie dopuścić do zbliżenia na polu kultury, które wydawało się niemożliwe ze względów ideowych ${ }^{29}$.

Polska, w opinii redakcji dziennika, wraz z innymi państwami podpisującymi konwencję o określeniu napastnika, pokazała, iż była państwem pragnącym pokoju. Podczas negocjacji, a także w samym dokumencie, jak wskazywał autor, uciekano od niejasności i gier dyplomatycznych, a jasno określono kto jest stroną napadającą. Dowodziło to w opinii publicysty pokojowych zamiarów państw sygnatariuszy. Pomimo tego, iż konwencja była aktem informacyjnym, to jak dowodził autor, miała ona wielkie znaczenie moralne i polityczne. Jako że głównym zagrożeniem dla redakcji wielkopolskiego dziennika była strona niemiecka, to z radością przyjęli oni pozbawienia Niemiec „mrzonek o wzięciu Polski w dwa ognie” ${ }^{30}$. Równocześnie podpisanie konwencji uznano za wielki sukces polskiej dyplomacji, wskazując na jej aktywność, podjęcie negocjacji pomiędzy ZSRR a Rumunią, co wyróżniało ją na zgnuśniałej i „pogrążonej w marazmie konferencji” ${ }^{11}$. Rekapitulując, publicyści związani z „Dziennikiem Poznańskim”, pozy-

\footnotetext{
28 J. W., Konsekwentna polityka, „Dziennik Poznański” 74 (I932) nr I7 I, s. I

29 J. Gutsche, Problem Rosji sowieckiej-a Wielkopolska, „Dziennik Poznański” 75 (I933) nr I3 I, s. I.

30 St. Wr., Zdemaskowana obtuda i prawdziwa praca dla pokoju, „Dziennik Poznański” 75 (1933) nr I 52, s. I.

3 I St. Wr., Zdemaskowana obtuda i prawdziwa praca dla pokoju, dz. cyt., s. I.
} 
tywnie podchodzili do prowadzonej przez Polskę dyplomacji, szczególnie, iż zabezpieczała ona ich zdaniem kraj przed niebezpieczeństwem niemieckim.

Niejako w opozycji do „Dziennika Poznańskiego” i jego stosunku do Związku Radzieckiego, jako potencjalnego sojusznika w walce z Niemcami, stanęło wileńskie „Słowo”. Piórami Stanisława Cata-Mackiewicza i Władysława Studnickiego wypracowano zgoła inną koncepcję geopolityczną, której nawet po podpisania paktu z bolszewikami broniono na łamach pisma. W odróżnieniu od środowiska wielkopolskiego, wileńscy zachowawcy postulowali, jako koniecznie, skupienie się polskiej polityki zagranicznej na zachodzie Europy. Gwarantem pokoju na kontynencie miał być pakt zawiązany pomiędzy trzema stolicami: Paryżem, Berlinem i Warszawą. Cat-Mackiewicz zachęcał do zrezygnowania z uprzedzeń w polityce względem Niemiec, szczególnie że, jak sam zauważał, Polska miała mniej punktów spornych z nimi niż Francja, która w tym czasie zabiegała o znormalizowanie stosunków ze swoim wschodnim sąsiadem ${ }^{32}$.

W opinii Mackiewicza dla zapewnienia pokoju dla Polski i Europy nie jest konieczny pakt o nieagresji ze Związkiem Radzieckim, tym bardziej że wcześniej uważał za możliwą interwencję na Wchodzie w celu powstrzymania sowieckiego zagrożenia, lecz pakt ów jako wariant wykluczał. Ewentualność podpisania paktu z Moskwą traktował on jako stwierdzenie kilku zaistniałych w ówczesnym czasie faktów, choć każdy pakt z krajem sąsiednim wzmacniał pokojowe otoczenie Polski. W jego opinii Związek Radziecki w bezpośredni sposób nie zagrażał Polsce, gdyż przez wzgląd na awanturniczą politykę w Azji i próbę wywołania rewolucji w brytyjskich koloniach, została wyeliminowana możliwość zbrojnej akcji na Zachodzie. Dlatego podpisanie paktu uważał za chwilowo słuszne i gwarantujące, iż Polska przystąpi jako ostatnia do interwencji przeciw sowietom. Jednakowoż ów pakt

32 S. Cat-Mackiewicz, Odszkodowania, anschluss, kolonie a korytarz i Gdańsk, „Słowo" I I (1932) nr I46, s. I. 
był dla niego rozwiązaniem chwilowym, póki Stalin nie ustabilizuje swych wschodnich granic, przez co nie wiązał z nim wielkich nadziei. Krytykował przy tym za zbyt optymistyczne podejście narodową demokrację, gdyż uważał za niemożliwe, by Sowieci w razie ataku Niemiec na Polskę, stali bezczynnie na naszych granicach ${ }^{33}$.

Podobnie studził nastroje Władysław Studnicki, choć zauważał jeden duży pozytyw, mianowicie podpisanie paktu o nieagresji stanowiło dla niego dowód braku poparcia dla idei komunistycznej w Polsce. W przypadku państw, w których niebezpieczeństwo zrewolucjonizowania mas istniało, ich rządy starały się ograniczyć do minimum kontakty z władzą bolszewicką. Z drugiej strony wzbraniał się przed wielkimi nadziejami związanymi z faktem podpisania owego dokumentu, szczególnie jeśli chodziło o możliwość przyszłego sojuszu. Bolszewicy, jak sam twierdził, jako dogmat traktowali przekształcenie przyszłej wojny w rewolucję europejską, czy też światową, dlatego w przypadku jej wybuchu nie stanie ona w obronie Polski, lecz udowadniał, iż będzie starała się zająć całe jej terytorium ${ }^{34}$. Podobnie rozumował Stanisław Mackiewicz, włączając w nurt rozważań geopolitycznych kwestię ustrojową, gdzie różnica pomiędzy omawianymi krajami była na tyle duża, iż niemożliwym było rozważanie przyszłego sojuszu. Odwoływał się on do metafory żołnierza walczącego na polu bitwy, który musi wierzyć, iż jego sojusznik wyznaje podobne wartości i będzie ich bronił za wszelką cenę, gdy tak się nie dzieje staje się on potencjalnym wrogiem ${ }^{35}$. Mackiewicz proroczo stwierdzał, iż nawet gdyby Moskwa stała się sojusznikiem Polski, to po pokonaniu Niemców pragnęłaby ona w zamian włączenia ziem Polskich do swojego imperium ${ }^{36}$.

33 S. Cat-Mackiewicz, Pakt o nieagresji z SSSR, „Słowo” I I (1932) nr I62, s. I.

34 W. Studnicki, Przesadne nadzieje i przesadny pesymizm, „Słowo” I I (1932) nr 205, s. I.

35 S. Cat-Mackiewicz, Pomiędzy podpisaniem paktu, a zjazdem w Gdyni. Żydzi, Masoni i Endecy, „Słowo” I I (1932) nr I95, s. I.

36 S. Cat-Mackiewicz, Pomiędzy podpisaniem paktu, a zjazdem w Gdyni..., dz. cyt. 
Studnicki traktował Związek Radziecki jako największe niebezpieczeństwo, z Niemcami w jego opinii mieliśmy tylko spór terytorialny, natomiast z sowietami, chodziło o całość urządzeń społeczno-ustrojowych i spór o niepodległość państwa na całym jego obszarze ${ }^{37}$. Studnicki posuwał się nawet dalej w swoich postulatach, które były całkowitym przeciwieństwem tych wysuwanych przez redakcję „Dziennika Poznańskiego”. Uważał, że w celu zneutralizowania zagrożenia sowieckiego, nie powinno się mówić o rozbrojeniu, lecz dozbrojeniu Niemiec, gdyż tylko one są w stanie powstrzymać ZSRR ${ }^{38}$.

$\mathrm{Z}$ drugiej strony Mackiewicz dostrzegał pewien plus w podpisaniu paktu o nieagresji. Pakt ten doprowadził do zerwania z polityką Rapalla i sparaliżował możliwość straszenia Europy przez Niemców przymierzem z sowietami. Z drugiej strony stale w jego rozważaniach obecna była koncepcja zwrotu ku zachodowi Europy ${ }^{39}$.

Podpisanie konwencji w Londynie traktował jeden z publicystów „Słowa”, w przeciwieństwie do autorów piszących w „Naszej Przyszłości”, nie jako ogromny sukces, lecz jako sprawne działanie dyplomacji sowieckiej. Władze ZSRR traktowały Polskę jako bramę do swoich terytoriów, dlatego wciągnięcie jej do swojej polityki zagranicznej, zabezpieczało w jego opinii państwo bolszewików od agresji niemieckiej $^{40}$. Myśl tę rozwijał Stanisław Mackiewicz, twierdząc, iż Rosja Sowiecka osiągnęła wpływy, szczególnie w Azji, niemożliwe dla Rosji carskiej. Jednocześnie zaznaczał, iż tych dwóch państw nie można było utożsamiać, a dokumentu uznawać za nowe urządzenie regionu państw słowiańskich, gdyż w przypadku ZSRR nie można używać przymiotników: rosyjskość, czy słowiańskość. Sowiecka wersja państwa, traktowana przez niego raczej jako Kościół, którego celem było

37 S. Cat-Mackiewicz, Pomiędzy podpisaniem paktu, a zjazdem w Gdyni..., dz. cyt.

38 W. Studnicki, Rosja w polityce światowej, „Słowo” I I (I932) nr I47, s. I.

39 S. Cat-Mackiewicz, Pakt o nieagresji z sowietami, „Słowo” I I (I932) nr I80, s. I.

40 K. Pruszyński, Poprzez wiersze jednej konwencji, „Słowo” I I (I932) nr I79, s. I. 
nawracanie siłą ${ }^{4 \mathrm{I}}$. Dlatego też uważał, iż tylko ignoranci mogli zachwiwerycać się polityką Litwinowa i określać ją jako pokojową. Bolszewizm miał nastawienie wojenne, a obawiając się ataku ze strony Niemiec zorganizował sobie system „poputczików”, sprzymierzeńców w walce z Hitlerem. Polska miała być wykorzystana przez ZSRR, a potem jako sprzymierzeniec zlikwidowana. Oskarżał on inny dziennik konserwatywny „Czas” o krótkowzroczność i brak racjonalnej analizy zagrożenia, jakie płynęło ze wzmocnienia komunizmu, a skupianie się tylko na ZSRR. Wskazywał na dwa powody takiego przedstawiania polityki wobec Związku Radzieckiego, po pierwsze myślenie tylko o zagrożeniu niemieckim i chęć zabezpieczenia się przed nim, choć Mackiewicz nie uważał tego niebezpieczeństwa za możliwe. Druga przyczyna, na jaką wskazywał, była natury psychicznej, rosyjskość miała nadal imponować, szczególnie, osobom pochodzącym, w przeciwieństwie do Mackiewicza, spoza kresów. Rosja nie istniała, lecz psychicznie rosyjskość nadal oddziaływała ${ }^{42}$.

Przypadek krytykowanego przez Mackiewicza „Czasu” jest niezwykle ciekawy w kontekście powyższych rozważań. Analizy dotyczące paktu o nieagresji rozpoczęły się jeszcze przed jego podpisaniem. Środowisko krakowskich zachowawców przyjęło możliwość podpisania dokumentu z umiarkowanym optymizmem. Uważano jednak to posunięcie jako w pełni racjonalne i wzmacniające pozycję Polski w Europie Środkowej, przy czym nie stroniono od negatywnych komentarzy, które dotyczyły spraw wewnętrznych w Związku Radzieckim. Podobnie jak w przypadku wcześniej omawianych tytułów, pakt ten analizowano przez pryzmat położenia Polski pomiędzy Niemcami a Rosją i łączących ich powiązań polityczno-gospodarczych. Fakt porozumienia z władzą sowiecką miał rozpoczynać nowy rozdział w stosunkach

4I S. Cat-Mackiewicz, Duży sukces dyplomacji sowieckiej, „Słowo” I 2 (I933) nr I 80, s. I.

42 S. Cat-Mackiewicz, ZSRRR zorganizowat „poputczików” w Europie, „Słowo” I 2 (I933) nr I 82, s.I. 
międzynarodowych i zakończyć układ sił zapoczątkowany w Rapallow3. Co więcej, wroga postawa hitlerowców, w połączeniu z coraz bardziej elastycznym podejściem Europy do kwestii powiązań gospodarczych z państwem bolszewickim, miała jeszcze bardziej osłabiać wspólną politykę Moskwy i Berlina, co przyjmowano z dużym zadowoleniem. Państwa te uważano za dążące w sposób najbardziej otwarty do obalenia porządku powersalskiego, który stanowił podstawę bytu państwa polskiego.

Popisanie paktu (co jest oryginalne w kontekście niniejszych rozważań) przedstawiano jako rezygnację polskich pretensji do przedrozbiorowych ziem, będących w posiadaniu ZSRR. Jednakże fakt ten uważano za możliwy do przyjęcia, jeśli uwzględni się korzyści wynikające z porozumienia. Poprzez ułożenie stosunków ze Związkiem Sowieckim, Polska nie tylko zabezpieczała wschodnie granice, lecz co równie ważne, otwierała sobie nowy rynek, gdyż naturalnym następstwem miał być pakt gospodarczy ${ }^{44}$.

Z dużą ostrożnością do negocjacji i możliwości podpisania paktu podchodził główny analityk kwestii sowieckich, czyli Edward Paszkowski. W jego opinii dokument ten niósł z sobą ogromne niebezpieczeństwo. Stalin miał przysięgać nad grobem Lenina, iż będzie dążył do rozszerzenia rewolucji na cały świat. Dlatego unormowanie stosunków pomiędzy Polską a ZSRR w jego opinii otwierało możliwość do większej aktywności agentury komunistycznej w Polsce. Uważał, że bolszewicy nie mogą wyrzec się chęci rozprzestrzeniania rewolucji, gdyż leżało to u samych podstaw komunizmu. Pakt o nieagresji mógł ograniczać wojskową działalność Stalina i zmuszał go do rezygnacji ze zbrojnej interwencji, lecz nie pozbawiał go możliwości walki ideologicznej poza granicami Związku Radzieckiego ${ }^{45}$.

\footnotetext{
43 Na marginesie paktu z sowietami, „Czas” 85 (I932) nr 22, s. I.

44 Na marginesie paktu z sowietami, „Czas” 85 (I932) nr 22, s. I.

45 E. Paszkowski, Przestrogi emigracji i wynurzenia bolszewickiej, „Czas” 85 (I932) nr 24, s. I.
} 
W miarę postępów w negocjacjach, a także późniejszego podpișania paktu, publicystyka krakowskiego dziennika stawała się coraz bardziej optymistyczna. Uważano, iż akt ten umacnia pozycję Polski w Europie Środkowo-Wschodniej, szczególnie jeśli chodzi o zabezpieczenie wschodniej flanki. Co ważne redakcja analizowała również podpisanie dokumentu przez pryzmat zobowiązań sojuszniczych Polski. Nieprzystąpienie Rumunii uważano za minus, lecz liczono, iż dojdzie ona do konsensusu z ZSRR. Z drugiej strony podkreślano, że informowano stronę francuską o negocjacjach i o jej zadowoleniu z pomyślnego ich zakończenia ${ }^{46}$. Podpisanie paktu uważano za jeden z najdonioślejszych momentów we współczesnej polityce międzynarodowej i opisywano go jako „akt dobrej woli tych państw, które wyrzekają się wszelkiej myśli o wojnie" ${ }^{47}$. Pomimo że Polska podpisywać miała dokument, co podkreślała redakcja bez entuzjazmu, to realizowała ona swoją misję w regionie. Uważano, iż miała ona stanąć na czele państw walczących o pokój oraz uchronić Europę Środkową od groźby wojny, co też czyniła przez umowę z ZSRR. Co więcej analizowany dokument stawiano jako wzór dla innych państw, gdyż nie zawierał on żadnych tajnych klauzul pomiędzy sygnatariuszami ${ }^{48}$.

Fakt wynegocjowania oraz podpisania konwencji o określeniu napaści przyjęto z wielką radością w redakcji czasopisma. Jak na ówczesne czasy, dokument miał być przełomowy i dawać możliwość zaistnienia trwałego pokoju pomiędzy państwami - sygnatariuszami. Za silną stronę dokumentu uważano jego regionalny charakter, co miało świadczyć o realizmie, w przeciwieństwie do ogólnoświatowych koncepcji pokojowych ${ }^{49}$.

Nie rezygnując z krytycznych uwag dotyczących szczególnie kwestii chłopskiej i losu Ukrainy sowieckiej, w roku 1933 komentarze, które

\footnotetext{
46 Dookota paktu o nieagresje, "Czas” 85 (I932) nr I72, s. I.

47 Pakt jakiego jeszcze nie byto, "Czas” 85 (I932) nr 298, s. I.

48 Pakt jakiego jeszcze nie byto, „Czas” 85 (I932) nr 298, s. I.

49 Wejście w życiu konwencji o napastniku, „Czas” 86 (I933) nr 242, s. I.
} 
dotyczyły stosunków panujących pomiędzy Warszawą a Moskwą, osiągnęły szczyt optymizmu, kreślono wręcz sielankowy obraz. To bezkrytyczne podejście do kwestii wschodniej najsilniej odróżniało "Czas” od innych pism konserwatywnych w Polsce. Poniższy cytat najlepiej świadczy o nastrojach ówcześnie panujących w redakcji:

Z czynnika zaborczego, awanturniczego Sowiety stały się czynnikiem pokojowym, stabilizacyjnym. Nie ma danych, by wątpić, że dzisiejsza pokojowość Sowietów jest szczera. Ze wszystkich kierunków sowieckich, kierunek Stalina jest najbardziej pokojowym, i możemy powiedzieć, dla nas najkorzystniejszym ${ }^{\text {so }}$.

Najostrzej na fakt zbliżenia polsko-sowieckiego zareagowała w swoich publikacjach redakcja „Buntu Młodych”. Wydała ona dwa artykuły jednoznacznie nieufne wobec umów międzynarodowych z wschodnim sąsiadem. W swoim artykule Aleksander Bocheński traktował bolszewików jako ruch mistyczno-religijny, który dążył do zapanowania nad światem. Asumpt do jego rozważań dała wizyta Karola Radka w Warszawie w 1933 roku $^{\text {sI }}$. Krytykował on głosy płynące ze strony polskich polityków i dziennikarzy, mówiące o przyjaźni między Polską a ZSRR. Uważał, iż przyjaźń taka jest niemożliwa, a podobne opinie wynikały z przyzwyczajenia, a także były wynikiem przepojenia propagandą. Aleksander Bocheński za niebezpieczne uważał tendencje pacyfistyczne rozprzestrzenione w Europie, które powoli opanowywały Polskę. Działo się to w momencie, gdy Związek Radziecki dokonywał wielkich zbrojeń, a zniewolone społeczeństwo było podporządkowane jednemu celowi, mianowicie rozprzestrzenianiu się rewolucji. Dlatego też Polska musiała, w opinii autora, odrzucać zbliżenie z państwem bolszewickim z dwóch powodów. Po pierwsze nie pozwalała na to polska racja stanu, a dodatkowo, co było prawdopodobnie waż-

\footnotetext{
50 Polska polityka zagraniczna, „Czas” 86 (I933) nr 218, s. I.

5 I W. Materski, Tarcza Europy: stosunki polsko-sowieckie I9I8-I939, Warszawa I 994 , s. 269.
} 
niejsze, na przyjaźń z bolszewikami nie pozwalało ludzkie poczucie dobra i zła ${ }^{52}$.

W drugim artykule Ryszard Wraga krytykował rzeczywistość, jaka nastała w Polsce po podpisaniu umów międzynarodowych z ZSRR. Działania mające na celu zbliżenie i obłaskawienie wschodniego sąsiada nie przynosiły w jego opinii zamierzonego efektu. Co więcej, podawał on szereg tytułów książek, a także artykułów, w których wypowiadano się skrajnie negatywnie na temat Polski i warunków w niej panujących. Najczęściej stosowanym określeniem było państwo faszystowskie, lecz jak przywołuje autor, pisano także o wyzysku robotników i chłopów. Jak słusznie zauważał Wraga, wszystkie wydawnictwa w ZSRR należały do państwa, więc wysuwał tezę, iż służyły one interesom partii. W takim wypadku negatywny obraz Polski w sowieckiej rzeczywistości miał być kreowany na zlecenie najwyższych polityków. Groźnie przedstawiała się również sytuacja w Polsce, gdzie „Wiadomości Literackie”, jak pisał autor, „za polskie pieniądze, wydawały sowieckie numery”. Dostrzegał on przy tym fałsz, jaki kreowali sowieccy politycy, uważający się za przedstawicieli państwowych, odcinając się od działalności komunistycznej. Autor nie dawał wiary takim zapewnieniom, uważając, że nie da się oddzielić działalności wywrotowej prowadzonej przez Komintern od sowieckich dygnitarzy i moskiewskich inspiracji. $\mathrm{Z}$ tego powodu wysuwał on żądanie, by obie strony były traktowane na równi. Jeśli w Polsce starano się robić wszystko, by nie urazić sowieckiego sojusznika, to władze bolszewickie także powinny powstrzymać się od szkodliwych dla polski komentarzy ${ }^{\varsigma 3}$.

Artykułem, który osłabiał bardzo ostry ton antysowiecki na łamach czasopisma, był tekst Witolda Prażmirskiego Handel z sowietami. Pisał go z punktu widzenia realizmu politycznego, co pozwoliło mu uważać

52 A. Bocheński, Nie, nie jesteśmy w przyjaźni z Bolszewją, „Bunt Młodych” 4 (I933) nr 45, s. I.

53 R. Wraga, Dwugtowy orzet w Leninowskim kąciku, „Bunt Młodych” 4 (1933) nr $47-48$, s. 8-9. 
handel z ZSRR za możliwy, a nawet, przy ówczesnej koniunkturze, korzystny. Jak sam analizował, okres, w którym Polska mogła zarobić najwięcej przez decyzje polityczne i układ międzynarodowy, nie został odpowiednio wykorzystany i prawdopodobnie bezpowrotnie zmarnowany. Jednakże uważał, iż polskie władze powinny się dostosować do wymogów chwili i wykorzystać nadarzającą się okazję do wzmocnienia wymiany handlowej ze wschodnim sąsiadem. Biorąc pod uwagę niepewność sytuacji w Związku Radzieckim oraz brak możliwości, w przypadku tego państwa, przewidywania przyszłości, sytuacja nie powinna być zmarnowana, jak zdarzało się to wcześniej ${ }^{54}$.

\section{Podsumowanie}

Kwestia wschodnia Polski stanowiła jedno z centralnych zagadnień polityki zagranicznej, które było analizowane na łamach prasy konserwatywnej. Zbliżenie, jakie dokonało się między Warszawą i Moskwą, które nastąpiło po podpisaniu dokumentów, wymienianych w w tekście Handel z sowietami, znalazło szczególny oddźwięk w przemyśleniach publicystów związanych z najważniejszymi z tytułami prasowymi wydawanymi przez polskich zachowawców. Uwarunkowanie czynnikami geopolitycznymi uwypukliło różnice w podejściu poszczególnych redakcji co do konsekwencji działań podejmowanych przez MSZ Polski. Szczególnie ważna wydaje się ewolucja owych poglądów, od jednoznacznie negatywnych do często, jak w przypadku „Czasu”, wręcz hurraoptymistycznych. Przy czym należy zaznaczyć, iż pomimo akceptacji polityki prowadzonej przez rząd sanacyjny, czy też jej wspierania, większa część publicystów dostrzegała zagrożenie płynące z kontaktów z ZSRR. Jednak każda z redakcji próbowała wypracować swoją koncepcję granic, których nie można było przekraczać, kierując się zyskiem z polepszonych stosunków dyplomatycznych.

54 W. Prażmirski, Handel z sowietami, „Bunt Młodych” 4 (I933) nr 42, s. I-2. 


\section{Streszczenie}

PUBLICYSTYKA WYBRANYCH CZASOPISM

KONSERWATYWNYCH WOBEC ZBLIŻENIA POLSKI I ZSRR

W LATACH 1932-1933

W latach 1932-I933 doszło do dwóch przełomowych wydarzeń w stosunkach między Polską a Związkiem Sowieckim. Pierwszym było podpisanie paktu o nieagresji w roku 1932, a rok później doszło do zawarcia w Londynie konwencji o określeniu napaści. Niniejszy artykuł ma na celu przedstawienie reakcji czasopism związanych z polskimi zachowawcami na zbliżenie pomiędzy wspomnianymi państwami. By dokonać rekonstrukcji dyskursu prowadzonego na łamach konserwatywnych czasopism, przeanalizowano najważniejsze tytuły związane z środowiskami polskich zachowawców: „Czas”, „Dziennik Poznański”, „Naszą Przyszłość”, „Politykę” oraz „Słowo”.

\section{Summary}

JOURNALISM OF SELECTED CONSERVATIVE JOURNALS REGARDING THE RAPPROCHEMENT BETWEEN POLAND AND THE USSR IN 1932-1933

Between 1932 and 1933, two significant changes took place in the Poland-Soviet Union relations. In 1932, the Soviet-Polish Non-Aggression Pact was signed, and year later the Convention for the Definition of Aggression was ratified in London. This paper aims to present the reaction to the rapprochement between these countries. In order to recreate the discourse in the conservative press, the most important newspapers such as "Czas", "Dziennik Poznański”, "Nasza Przyszłość", "Polityka" and "Słowo" have been analyzed. 


\section{Bibliografia}

Bartyzel J., Konserwatyzm bez kompromisu. Studium z dziejów zachowawczej myśli politycznej w Polsce w XX wieku, Toruń 2002.

Materski W., Na widecie. II Rzeczpospolita wobec sowietów I9I8-I943, Warszawa 2005 .

Materski W., Tarcza Europy: stosunki polsko-sowieckie, I9I8-I939, Warszawa 1994.

Rudnicki S., Władyka W., Prasa konserwatywna Drugiej Rzeczpospolitej. Zarys problematyki i przeglad tytutów, „Rocznik Historii Czasopiśmiennictwa Polskiego" I4 (I975) nr 4, s. 409-465.

Szlachta B., Krytyka komunizmu w polskiej myśli katolickiej i konserwatywnej, w: Antykomunizm po komunizmie, red. J. Kloczkowski, Kraków 2002, s. 15-49.

Władyka W., Publicystyka polityczna neokonserwatystów w latach I9261935, „Rocznik Historii Czasopiśmiennictwa Polskiego” I5 (1976) nr 4, s. 459-460.

Zackiewicz G., Polska myśl polityczna wobec systemu radzieckiego I9I8I939, Kraków 2004. 
A. Uniwersytet Papieski

过, Jana Pawła II

(b w Krakowie 
A. Uniwersytet Papieski

过, Jana Pawła II

(b w Krakowie 